\title{
Parasitological correlates of Plasmodium ovale curtisi and Plasmodium ovale wallikeri infection
}

Melissa S. Phuong ${ }^{1}$, Rachel Lau², Filip Ralevski ${ }^{2}$ and Andrea K. Boggild $2,3,4^{*}$

\begin{abstract}
Background: Malaria, due to Plasmodium ovale, can be challenging to diagnose due to clinically mild disease and low parasite burden. Two genetically distinct sub-species of P. ovale exist: Plasmodium ovale curtisi (classic) and Plasmodium ovale wallikeri (variant). It is presently unknown if the sub-species causing infection affects performance of malaria diagnostic tests. The aim of this work was to understand how the genetically distinct sub-species, P. o. curtisi and P. o. wallikeri, affect malaria diagnostic tests.
\end{abstract}

Methods: Plasmodium ovale-positive whole blood specimens were sub-speciated by PCR and sequencing of $18 \mathrm{~S}$

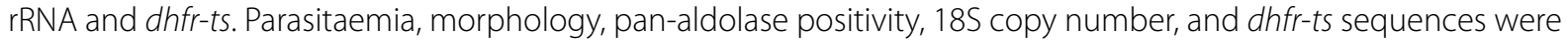
compared between sub-species.

Results: From 2006 to 2015, 49 P. ovale isolates were identified, of which 22 were P. o. curtisi and 27 P. o. wallikeri; 80\% were identified in the last five years, and $88 \%$ were acquired in West Africa. Sub-species did not differ by parasitaemia, $18 \mathrm{~S}$ copy number, or pan-aldolase positivity. Lack of Schüffner's stippling was over-represented among P. o. wallikeri isolates $(p=0.02)$. Several nucleotide polymorphisms between the sub-species were observed, but they do not occur at sites believed to relate to antifolate binding.

Conclusions: Plasmodium ovale is increasing among travellers to West Africa, although sub-species do not differ significantly by parasitologic features such as parasitaemia. Absence of Schüffner's stippling may be a feature specific to P. O. wallikeri and is a novel finding.

Keywords: Plasmodium ovale, Malaria diagnosis, Microscopy, PCR, Rapid antigen detection test

\section{Background}

Plasmodium ovale is one species of malaria parasites that is pathogenic to humans [1]. Prevalent in West and East Africa and the Asia-Pacific [1], P. ovale infections can be challenging to diagnose in part due to the typical presentation of clinically mild disease and low parasite burden [2]. Consequently, conventional diagnostic tools, such as microscopy of blood films and rapid diagnostic tests (RDT), have limited performance in detecting $P$. ovale infection [3-5], often resulting in the use of molecular techniques to confirm the diagnosis [5].

\footnotetext{
*Correspondence: andrea.boggild@utoronto.ca

${ }^{4}$ University of Toronto, Toronto, Canada

Full list of author information is available at the end of the article
}

Two genetically distinct sub-species of $P$. ovale exist: Plasmodium ovale curtisi and Plasmodium ovale wallikeri $[7,8]$, which are known as the classic and variant types, respectively. First recognized in 2010, these two sub-species are believed to have diverged one to two million years ago [7, 9]. Clinical differences between the two sub-species have not been clearly elucidated, although there have been differences found in latency period [9] and thrombocytopaenia [10]. At present, it is unknown if the performance of malaria diagnostic tests may differ between the sub-species, causing infection. It is known that the dihydrofolate reductase-thymidylate synthase $(d h f r-t s)$ domain, a common anti-malarial drug target and a region that can be linked to antifolate resistance, has been thoroughly investigated in Plasmodium 
falciparum and Plasmodium vivax. However, investigations into this region have only recently begun for $P$. ovale isolates $[2,8,11]$. Previous reports have implicated specific sites in the peptide sequence that may interfere with antifolate binding at the active site, which include D53, F57, S58, T61, S113, S116, I169, and T190 [8, 11]. $\mathrm{R} 499 / 503$ and C519/523 (P. ovale curtisi/P. ovale wallikeri) are also believed to be significant for thymidylate synthase activity, specifically [8]. As atovaquone-proguanil, the proguanil component of which is an antifolate, is one of the most commonly and empirically used antimalarials for travel-acquired malaria, it is important to understand if mutations in regions of $d h f r$-ts known to confer resistance in other species of malaria are present in $P$. ovale isolates, and if these mutations are specific to one sub-species over another.

Further understanding of parasitologic correlates of $P$. ovale sub-species may have important implications for diagnosis and management. The potential differences in parasite burden, RDT performance, morphology, and molecular diagnosis between $P$. ovale curtisi and $P$. ovale wallikeri were investigated. The DHFR-TS peptide sequence was also compared between isolates to investigate potential mutations in regions known to confer antifolate resistance in other species of malaria.

\section{Methods}

\section{Specimens}

Plasmodium ovale-positive, whole blood specimens stored in the malaria biobank at Public Health Ontario Laboratories (PHOL) from October 2006 to July 2015 were identified and retrieved. For the staining procedure, $2 \mathrm{~mL}$ of standard Giemsa stain was diluted in $48 \mathrm{~mL}$ of phosphate buffer ( $\mathrm{pH}$ 7.1) prior to use. The phosphate buffer consists of $65 \mathrm{~mL}$ of $\mathrm{Na}_{2} \mathrm{HPO}_{4}, 35 \mathrm{~mL}$ of $\mathrm{NaH}_{2} \mathrm{PO}_{4}$, and $900 \mathrm{~mL}$ of distilled water, resulting in 4.35 and $2.33 \mathrm{mM}$ concentrations, respectively. For thin films, the slide was immersed in methanol for $10 \mathrm{~s}$, allowed to dry, and then immersed in the working Giemsa solution for $10 \mathrm{~min}$. The slide was then immersed in phosphate buffer solution for $10 \mathrm{~s}$ and air dried. Thick films were immersed in the working Giemsa solution for $10 \mathrm{~min}$, immersed in the phosphate buffer for $30 \mathrm{~s}$, and air dried. With each working solution prepared, a control P. falciparum slide was prepared and examined. Parasitaemia, morphological features, pan-aldolase antigen-positivity as determined by the BinaxNOW Malaria test (Alere, Ottawa, ON, Canada), year of import, and country of acquisition that were recorded in the biobank database following initial diagnostic processing were collected and analysed. The study was approved by the Research Ethics Board of Public Health Ontario.

\section{DNA extraction}

DNA of all specimens was extracted using the DNA Mini Kit Blood or Body Fluid Spin Protocol (Qiagen, Germantown, MD, USA). Prior to use, DNA was stored at $-20^{\circ} \mathrm{C}$.

\section{Qualitative and quantitative real-time PCR}

Plasmodium falciparum/P. vivax species-specific duplex [6] and Plasmodium malariae/P. ovale species-specific duplex real-time PCR (qPCR) assays were conducted to confirm microscopy species identification as previously described [12]. All qPCR assays were run under the following conditions using the ABI 7900HT qPCR system: $50{ }^{\circ} \mathrm{C}$ for $2 \mathrm{~min}, 95^{\circ} \mathrm{C}$ for $10 \mathrm{~min}, 95^{\circ} \mathrm{C}$ for $15 \mathrm{~s}$, and $60^{\circ} \mathrm{C}$ for $1 \mathrm{~min}$ ( 45 cycles); $12.5 \mu \mathrm{l}$ of TaqMan universal PCR master mix (Life Technologies, Burlington, ON, Canada) and $5 \mu \mathrm{l}$ of DNA primers and probes with concentrations as previously reported $[6,12,13]$ were used, for a final volume of $25 \mu \mathrm{l}$ per reaction. All qPCR amplification curves were analysed using a manual threshold cycle of 0.02 and an automatic baseline. A cycle threshold $(\mathrm{Ct})$ of $<38$ was considered to be a positive result.

18S rRNA gene copy numbers were quantified by running the $P$. malariae/P. ovale species-specific duplex qPCR assay and including serial dilutions of a $P$. ovale clone (ATCC, Manassas, VA, USA) alongside specimen DNA in triplicates. A linear regression was then constructed based on the logarithm of the gene copy number and $\mathrm{Ct}$ values for each concentration of the clone. This equation could then be used to calculate the gene copy number for each banked specimen.

\section{Sequencing of $18 \mathrm{~S}$ rRNA and dihydrofolate reductase-thymidylate synthase}

Endpoint PCR of target regions, visualization of the amplicons on agarose gel, and Sanger sequencing were conducted as previously described [12]. Specifically, endpoint PCR of a 396-bp product from the 18S rRNA region was conducted with high-fidelity polymerase AccuPrime Pfx Supermix (Life Technologies, Burlington, ON, Canada) and $200 \mathrm{nM}$ (each) of the primers Plasmo $18 \mathrm{~S}$ forward (5'-ATTCAGATGTCAGAGGTG AAATTCT-3') and Plasmo $18 \mathrm{~S}$ reverse (5'-TCAATCC TACTCTTGTCTTAAACTA-3'). Using an ABI Veriti fast thermal cycler, the cycling conditions were $95^{\circ} \mathrm{C}$ for $5 \mathrm{~min}$, followed by $95^{\circ} \mathrm{C}$ for $15 \mathrm{~s}, 58^{\circ} \mathrm{C}$ for $30 \mathrm{~s}$, and $68^{\circ} \mathrm{C}$ for $30 \mathrm{~s}$ for 45 cycles, and then $68{ }^{\circ} \mathrm{C}$ for $5 \mathrm{~min}$. Amplicons were visualized on $1 \%$ agarose gels with ethidium bromide prior to Sanger sequencing. For sequencing, the same forward and reverse primers were used along with a BigDye Terminator v3.1 cycle sequencing kit (Life Technologies, Burlington, ON, Canada), which was run 
according to the manufacturer's recommended conditions. The products were purified by a BigDye XTerminator (Life Technologies, Burlington, ON, Canada) and analysed with an ABI 3130xl genetic analyzer. Forward and reverse sequences of each sample were aligned using Vector NTI software (Life Technologies, Burlington, ON, Canada), and the sequences were verified using a BLAST search to confirm the sub-species identification [14].

Primers for sequencing the dhfr-ts gene were newly designed for this study. All primers were designed using Primer3 $[15,16]$ and predominantly conserved regions of the complete sequence of the $P$. ovale dhfrts gene (GenBank: EU266602). Degenerate nucleotides were included based on the dhfr-ts gene for $P$. $o$. curtisi (GenBank: KP050414) and P. o. wallikeri (GenBank: KP050415). Endpoint PCR of the dihydrofolate reductase-thymidylate synthase region was conducted on all specimens with high-fidelity polymerase Phusion (New England BioLabs, Ipswich, MA, USA) and $200 \mathrm{nM}$ (each) of the primers PocPowDHFR-exF (5'-YTCWACC TTCAGGGGTATCG-3') and PocPowDHFR-exR (5'-AG TTTWAGCGTGGGRAAAGG-3'), generating an approximately 1700 -bp product that covers the 99th amino acid to 1814-1826th amino acid of the sequence, where the end target varies based on the sub-species. The cycling conditions were $98^{\circ} \mathrm{C}$ for $30 \mathrm{~min}$, followed by $98{ }^{\circ} \mathrm{C}$ for $10 \mathrm{~s}, 64{ }^{\circ} \mathrm{C}$ for $30 \mathrm{~s}$, and $72{ }^{\circ} \mathrm{C}$ for $1 \mathrm{~min}$ for 40 cycles, and then $72{ }^{\circ} \mathrm{C}$ for 10 min using an ABI Veriti fast thermal cycler. Visualization and Sanger sequencing of the PCR products were performed identically compared to the 18S rRNA methodology with the exception of the primers used. For sequencing, PocPowDHFRexF, PocPowDHFR-exR, and a third internal primer, PocPowDHFR-inR (5'-TTTCCATTKGTTTCCCCTC $\left.\mathrm{T}-3^{\prime}\right)$ were used. Sequences for each specimen were aligned and verified using a BLAST search to further confirm the sub-species identification. Alignments of $P$. ovale sequences were performed using Mega6 software [17]. Genetic and peptide sequences between the enrolled specimens and complete $P$. ovale sequences that were previously reported (GenBank: EU266601, EU266604EU266618, GQ250090, GQ250091, KP050409, and KP05413-KP050415) [2, 7, 18] were compared.

\section{Statistical analysis}

Reported parasitaemia, morphological features (including Schüffner's stippling), pan-aldolase antigen-positivity, $18 \mathrm{~S}$ gene copy number, year of import, and region of acquisition were compared between the two sub-species. Parasitaemia was treated as categorical data by recording if the percentage of parasites observed were $<0.1$ or $\geq 0.1 \%$, as the former category is a convention used by PHOL laboratory technicians. Categorical variables were compared using Yates' corrected Chi squared analysis or Fisher's exact test, and continuous variables using Mann-Whitney U tests using GraphPad Prism 6 (GraphPad Software, CA, USA). Level of significance was set at $\mathrm{p}<0.05$.

\section{Results}

Of 49 isolates of $P$. ovale identified from October 2006 to July 2015 , ten $(20.4 \%)$ were identified through 2010 , while $39(79.6 \%)$ were identified in or after the year 2011, with 24 (49\%) identified in 2013 or 2014, the last two full years in the enrolment period. Country of exposure data were available for $17 / 49$ (34.7\%) specimens, with Nigeria being the most well represented source country $(\mathrm{n}=9,18.4 \%)$. Of the 17 isolates with an attached travel history, 15 (88.2\%) were acquired in West Africa, with represented source countries of Nigeria, Ghana $(n=2)$, Ivory Coast $(\mathrm{n}=1)$, Liberia $(\mathrm{n}=1)$, Sierra Leone $(\mathrm{n}=1)$, Congo $(n=1)$, and Cameroon $(n=1)$. Two isolates were imported from East or Saharan Africa, one each from Tanzania and the Sudan.

Of 49 total isolates, 22 P. ovale curtisi and 27 P. ovale wallikeri isolates were identified by $18 \mathrm{~S}$ rRNA sequencing (Table 1). Region of acquisition did not differ between sub-species $(\mathrm{p}=1.00)$. Both sub-species appeared to emerge simultaneously in the past five years, with no difference between sub-species: six (27.3\%) isolates of $P$. ovale curtisi were identified prior to 2011, and 16 (72.7\%) in or after 2011, compared to four (14.8\%) isolates of $P$. ovale wallikeri identified prior to 2011, and $23(85.2 \%)$ in or after $2011(\mathrm{p}=0.31)$ (Fig. 1).

\section{Microscopy and RDT}

Records of pan-aldolase antigen result and morphological features were absent for one specimen, resulting in the omission of this isolate from relevant calculations. Median parasitaemia (by microscopy) of specimens positive for $P$. ovale curtisi was $<0.1 \%$ (range $<0.1-0.8 \%$ ), while for $P$. ovale wallikeri it was $<0.1 \%$ (range $<0.1-$ $0.5 \%)$, and no difference was found $(\mathrm{p}=0.99)$. There was no difference found in pan-aldolase antigen-positivity, where it was detectable in $11(50.0 \%)$ specimens containing $P$. ovale curtisi and 11 (42.3\%) specimens containing P. ovale wallikeri $(\mathrm{p}=0.81)$. Pan-aldolase positivity for all specimens was $45.8 \%$.

When comparing morphological features (Table 2), it was noted that all eight $P$. ovale parasites without Schüffner's stippling were $P$. ovale wallikeri $(\mathrm{p}=0.02)$ (Fig. 2). Parasitaemia $(\mathrm{p}=0.20), 18 \mathrm{~S}$ rRNA gene copy number $(\mathrm{p}=0.50)$, and pan-aldolase antigen positivity $(\mathrm{p}=0.40)$, were not found to be differentially associated with Schüffner's stippling. Data on time between specimen collection and receipt were missing for two $P$. 
Table 1 Pan-aldolase antigen-positivity (T2), parasitaemia, 18S rRNA gene copy number, reported Schüffner's stippling, and the number of days between blood collection and processing Plasmodium ovale curtisi and Plasmodium ovale wallikeri specimens are recorded

\begin{tabular}{|c|c|c|c|c|c|c|c|c|}
\hline $\begin{array}{l}\text { Specimen } \\
\text { number }\end{array}$ & Sub-species & Aldolase & $\begin{array}{l}\text { Parasitaemia } \\
(\%)\end{array}$ & $\begin{array}{l}\text { 18S rRNA } \\
\text { gene copy } \\
\text { number/ } \mu \mathrm{L} \\
\text { blood }\end{array}$ & $\begin{array}{l}\text { Schüffner's } \\
\text { stippling }\end{array}$ & $\begin{array}{l}\text { Number of days } \\
\text { between blood } \\
\text { collection } \\
\text { and processing }\end{array}$ & $\begin{array}{l}\text { Year of } \\
\text { import }\end{array}$ & $\begin{array}{l}\text { Country } \\
\text { of acquisition }\end{array}$ \\
\hline 1 & P. ovale curtisi & + & 0.8 & 11,649 & + & 1 & 2014 & Ivory Coast \\
\hline 2 & P. ovale curtisi & + & 0.6 & 5054 & + & 1 & 2014 & Nigeria \\
\hline 3 & P. ovale curtisi & - & 0.3 & 2132 & + & 7 & 2014 & Unknown \\
\hline 4 & P. ovale curtisi & + & 0.3 & 1928 & + & 1 & 2014 & Unknown \\
\hline 5 & P. ovale curtisi & + & 0.2 & 16,807 & + & 0 & 2012 & Unknown \\
\hline 6 & P. ovale curtisi & + & 0.2 & 626 & + & 0 & 2014 & Unknown \\
\hline 7 & P. ovale curtisi & + & 0.2 & 831 & + & 0 & 2014 & Unknown \\
\hline 8 & P. ovale curtisi & + & 0.1 & 3093 & NA & NA & 2006 & Unknown \\
\hline 9 & P. ovale curtisi & + & 0.1 & 8445 & + & 1 & 2011 & Ghana; Nigeria \\
\hline 10 & P. ovale curtisi & - & $<0.1$ & 8264 & + & 1 & 2009 & Unknown \\
\hline 11 & P. ovale curtisi & - & $<0.1$ & 3285 & + & NA & 2009 & Nigeria \\
\hline 12 & P. ovale curtisi & - & $<0.1$ & 1765 & + & 0 & 2010 & Unknown \\
\hline 13 & P. ovale curtisi & - & $<0.1$ & 931 & + & 0 & 2010 & Unknown \\
\hline 14 & P. ovale curtisi & - & $<0.1$ & 1972 & + & 0 & 2011 & Ghana \\
\hline 15 & P. ovale curtisi & + & $<0.1$ & 4962 & + & NA & 2007 & Unknown \\
\hline 16 & P. ovale curtisi & - & $<0.1$ & 302 & + & 1 & 2012 & Unknown \\
\hline 17 & P. ovale curtisi & - & $<0.1$ & 855 & + & 0 & 2014 & Nigeria \\
\hline 18 & P. ovale curtisi & + & $<0.1$ & 2088 & + & 1 & 2015 & Nigeria \\
\hline 19 & P. ovale curtisi & - & $<0.1$ & 538 & + & 1 & 2013 & Tanzania \\
\hline 20 & P. ovale curtisi & + & $<0.1$ & 2991 & + & NA & 2014 & Unknown \\
\hline 21 & P. ovale curtisi & - & $<0.1$ & 325 & + & 1 & 2014 & Unknown \\
\hline 22 & P. ovale curtisi & - & $<0.1$ & 2637 & + & 1 & 2013 & Unknown \\
\hline 23 & P. ovale wallikeri & - & 0.5 & 12,709 & - & 0 & 2011 & Unknown \\
\hline 24 & P. ovale wallikeri & + & 0.5 & 2835 & - & 0 & 2014 & Unknown \\
\hline 25 & P. ovale wallikeri & + & 0.4 & 5013 & + & 0 & 2013 & Unknown \\
\hline 26 & P. ovale wallikeri & + & 0.3 & 7107 & + & 1 & 2008 & Unknown \\
\hline 27 & P. ovale wallikeri & - & 0.3 & 6826 & + & 0 & 2011 & Sudan \\
\hline 28 & P. ovale wallikeri & + & 0.3 & 15,840 & + & 4 & 2012 & Liberia \\
\hline 29 & P. ovale wallikeri & + & 0.3 & 8697 & + & 0 & 2012 & Nigeria \\
\hline 30 & P. ovale wallikeri & + & 0.3 & 3897 & + & 0 & 2014 & Unknown \\
\hline 31 & P. ovale wallikeri & - & 0.15 & 114 & + & 1 & 2013 & Unknown \\
\hline 32 & P. ovale wallikeri & + & 0.1 & 2160 & + & 0 & 2013 & Unknown \\
\hline 33 & P. ovale wallikeri & - & 0.1 & 91 & + & 0 & 2014 & Unknown \\
\hline 34 & P. ovale wallikeri & - & $<0.1$ & 985 & - & 0 & 2009 & Unknown \\
\hline 35 & P. ovale wallikeri & + & $<0.1$ & 4402 & + & 1 & 2010 & Unknown \\
\hline 36 & P. ovale wallikeri & - & $<0.1$ & 752 & + & 1 & 2011 & Unknown \\
\hline 37 & P. ovale wallikeri & - & $<0.1$ & 935 & + & 0 & 2011 & Sierra Leone \\
\hline 38 & P. ovale wallikeri & - & $<0.1$ & 538 & + & 1 & 2012 & Unknown \\
\hline 39 & P. ovale wallikeri & - & $<0.1$ & 739 & - & 1 & 2013 & Unknown \\
\hline 40 & P. ovale wallikeri & NA & $<0.1$ & 4 & + & 2 & 2009 & Nigeria \\
\hline 41 & P. ovale wallikeri & - & $<0.1$ & 364 & + & 0 & 2012 & Congo \\
\hline 42 & P. ovale wallikeri & + & $<0.1$ & 1898 & - & NA & 2013 & Cameroon \\
\hline 43 & P. ovale wallikeri & + & $<0.1$ & 435 & + & 0 & 2014 & Unknown \\
\hline 44 & P. ovale wallikeri & - & $<0.1$ & 51 & + & 0 & 2013 & Nigeria \\
\hline 45 & P. ovale wallikeri & + & $<0.1$ & 45 & + & 1 & 2014 & Unknown \\
\hline
\end{tabular}


Table 1 continued

\begin{tabular}{|c|c|c|c|c|c|c|c|c|}
\hline $\begin{array}{l}\text { Specimen } \\
\text { number }\end{array}$ & Sub-species & Aldolase & $\begin{array}{l}\text { Parasitaemia } \\
(\%)\end{array}$ & 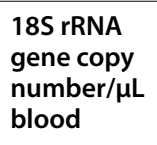 & $\begin{array}{l}\text { Schüffner's } \\
\text { stippling }\end{array}$ & $\begin{array}{l}\text { Number of days } \\
\text { between blood } \\
\text { collection } \\
\text { and processing }\end{array}$ & $\begin{array}{l}\text { Year of } \\
\text { import }\end{array}$ & $\begin{array}{l}\text { Country } \\
\text { of acquisition }\end{array}$ \\
\hline 46 & P. ovale wallikeri & - & $<0.1$ & 256 & - & 1 & 2013 & Nigeria \\
\hline 47 & P. ovale wallikeri & - & $<0.1$ & 488 & + & 0 & 2013 & Unknown \\
\hline 48 & P. ovale wallikeri & - & $<0.1$ & 187 & - & NA & 2012 & Unknown \\
\hline 49 & P. ovale wallikeri & - & $<0.1$ & 571 & - & 0 & 2015 & Unknown \\
\hline
\end{tabular}

NA not available

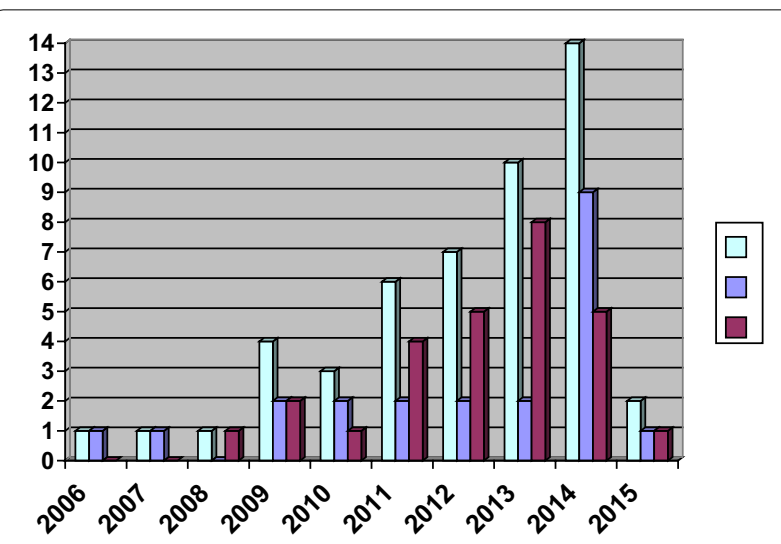

Fig. 1 Plasmodium ovale isolates confirmed by Public Health Ontario Laboratories by year of import. 2006 and 2015 represent partial calendar years (October-December 2006, and January-June 2015). Emergence of $P$. ovale was equally distributed among the two sub-species, with six (27.3\%) isolates of $P$. ovale curtisi identified prior to 2011 , and 16 (72.7\%) in or after 2011, compared to four (14.8\%) isolates of P. ovale wallikeri identified prior to 2011, and 23 (85.2\%) in or after $2011(p=0.31)$

Table 2 Number of isolates with Schüffner's stippling noted at Giemsa-stained microscopy of specimens positive for Plasmodium ovale

\begin{tabular}{lll}
\hline $\begin{array}{l}\text { Plasmodium ovale } \\
\text { sub-species }\end{array}$ & $\begin{array}{l}\text { Schüffner's stippling } \\
\text { noted }\end{array}$ & $\begin{array}{l}\text { Schüfner's stippling } \\
\text { not noted }\end{array}$ \\
\hline $\begin{array}{l}\text { Plasmodium ovale } \\
\text { curtisi }\end{array}$ & 21 & 0 \\
$\begin{array}{l}\text { Plasmodium ovale } \\
\text { wallikeri }\end{array}$ & 19 & 8 \\
\hline
\end{tabular}

ovale wallikeri specimens without Schüffner's stippling, and four $P$. ovale curtisi specimens, where three $P$. ovale curtisi specimens had Schüffner's stippling and the other specimen had no morphological features recorded. No significant difference in time for specimen processing between specimens with and without Schüffner's stippling was noted $(\mathrm{p}=0.57)$.

\section{$18 S$ gene copy number}

$18 \mathrm{~S}$ rRNA gene copy number was found to be not normally distributed among all samples based on the D'Agostino-Pearson normality test, $\mathrm{p}<0.0001$. Median $18 \mathrm{~S}$ rRNA gene copy number for $P$. ovale curtisi and $P$. ovale wallikeri were $2110 / \mu \mathrm{L}$ (range $302-16,807 / \mu \mathrm{L}$ ) and $844 / \mu \mathrm{L}$ (range $4-15,840 / \mu \mathrm{L})$, respectively $(\mathrm{p}=0.09)$.

\section{Dihydrofolate reductase-thymidylate synthase (dhfr-ts)}

Partial sequences of $d f h r-t s$ could be obtained in $16 P$. ovale wallikeri and seven $P$. ovale curtisi. In 26/49 isolates, the $d h f r$-ts region selected could not be amplified by the selected primer set. Several differences in the peptide sequences between $P$. ovale curtisi and $P$. ovale wallikeri were observed (Table 3). Non-synonymous mutations were observed within the $P$. ovale wallikeri isolates as previously reported [2]. Specifically, deletions of two or four amino acids (i.e., TA252-253 or TATA252-255) were identified in six and one $P$. ovale wallikeri isolates, respectively (Table 3 ). Furthermore, due to an ambiguity in the nucleic acid sequence, potential Y359F and Y366F mutations were observed. Finally, for one specimen, a H285Q mutation was recorded for one P. ovale wallikeri isolate. While Y359F and Y366F mutations are not expected to change any amino acid properties, a H285Q indicates a change from a basic histidine to a polar, uncharged glutamine. Among the sequences analysed in this study, polymorphisms specific to either sub-species were not observed (Table 4). One P. ovale wallikeri specimen did have a I169L mutation, although this does not reflect any changes in amino acid properties.

\section{Discussion}

Plasmodium ovale is increasingly observed among travellers, and due to its ability to relapse months to years after primary infection; unlike the more common and severe P. falciparum, its ability to inflict acute morbidity continues long after the immediate post-travel period. The data reported herein underscore the anecdotal impression among laboratory personnel that $P$. ovale is increasing 

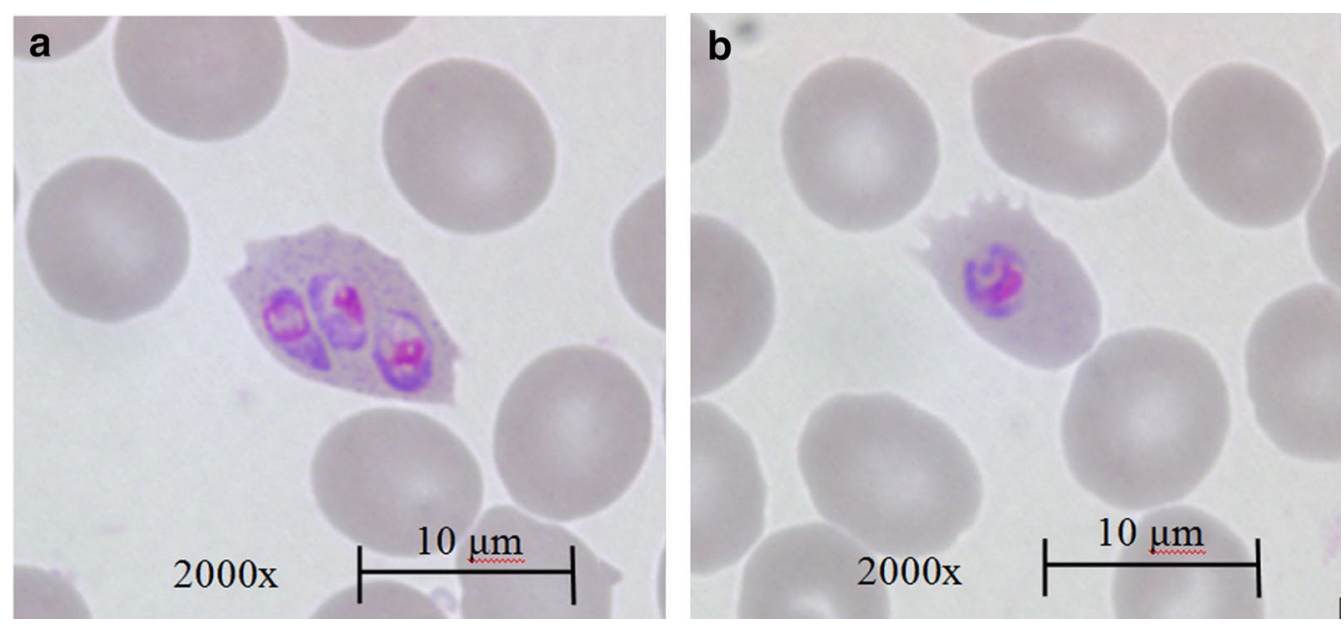

Fig. 2 Giemsa-stained microscopy of Plasmodium ovale. Note prominent Schüffner's stippling in a, compared to the absence of Schüffner's stippling in $\mathbf{b}$

among travellers returning from West Africa, with almost $80 \%$ of imports to PHOL occurring in the last five years. Between 2007 and 2012, P. ovale diagnoses climbed from one per year to eight per year at PHOL [12]. Although it appeared in this study that many more $P$. ovale wallikeri isolates were imported in the past five years compared to $P$. ovale curtisi, this difference was not significant, although with higher numbers over a longer enrolment period such a difference may emerge.

Due to widespread attrition of trained microscopists in laboratories of non-malaria endemic regions, such as North America, diagnosis of malaria is becoming increasingly reliant on RDT and molecular methods. However, given the extremely poor sensitivity of standard RDT for $P$. ovale infection [19], as well as typically low parasitaemia, under- and delayed diagnosis are increasingly likely. In addition, diagnostic morphologic features may not be demonstrable in the setting of extremely low parasitaemia, prompting empiric use of anti-malarials for a patient whose malaria screen is initially reported as "Plasmodium spp." pending confirmatory molecular analysis. Standard choice of empiric oral therapy for uncomplicated malaria in North America is usually either atovaquone-proguanil (AP), or more rarely, artemether-lumefantrine. As resistance to the proguanil component of AP is conferred in $P$. falciparum by step-wise mutations of the Dhfr gene, understanding whether or not similar mutations can accumulate in $P$. ovale, and whether such mutations are over-represented among a particular sub-species of $P$. ovale, is important for informing empiric choice of antimalarials in a patient with unspeciated malaria.

Among peptide sequences of DHFR-TS in isolates of $P$. ovale curtisi and $P$. ovale wallikeri studied herein, mutations known to confer antifolate resistance in other species of malaria, notably $P$. falciparum were not demonstrated Furthermore, non-synonymous mutations within each sub-species, $P$. ovale wallikeri in particular, were also observed, confirming previous reports [2]. While there are variations in the peptide sequences between sub-species, it is unknown how these polymorphisms influence enzyme activity. Amino acids in the DHFR-TS that are believed to be involved in antifolate binding, and which are believed to be synonymous with amino acids found in other Plasmodium species, were found to be consistent throughout all examined $P$. ovale specimens, regardless of sub-species. These findings suggest that the lack of clinical treatment failures observed in patients with $P$. ovale correlate well to gene sequences free of known markers of resistance, and are reassuring from the perspective of empiric choice of anti-malarials. It would be very unlikely, and unfortunate, for a traveller from West Africa with unspeciated malaria to be started empirically on chloroquine, which is actually the drug of choice for P. ovale, rather than AP.

Many reports have documented the existence of the two sub-species of $P$. ovale; it was previously unknown if parasitaemia, $18 \mathrm{~S}$ rRNA gene copy number and the detection of the pan-aldolase antigen in BinaxNow RDT could differ between them. The results reported herein indicate that $P$. ovale curtisi and $P$. ovale wallikeri do not differ significantly by parasitaemia, pan-aldolase antigenpositivity or $18 \mathrm{~S}$ rRNA gene copy number. A general low pan-aldolase antigen-positivity rate among all specimens was observed, which is consistent with previous literature $[19,20]$. A lack of discernible Schüffner's stippling may be a feature specific to $P$. ovale wallikeri, and may 


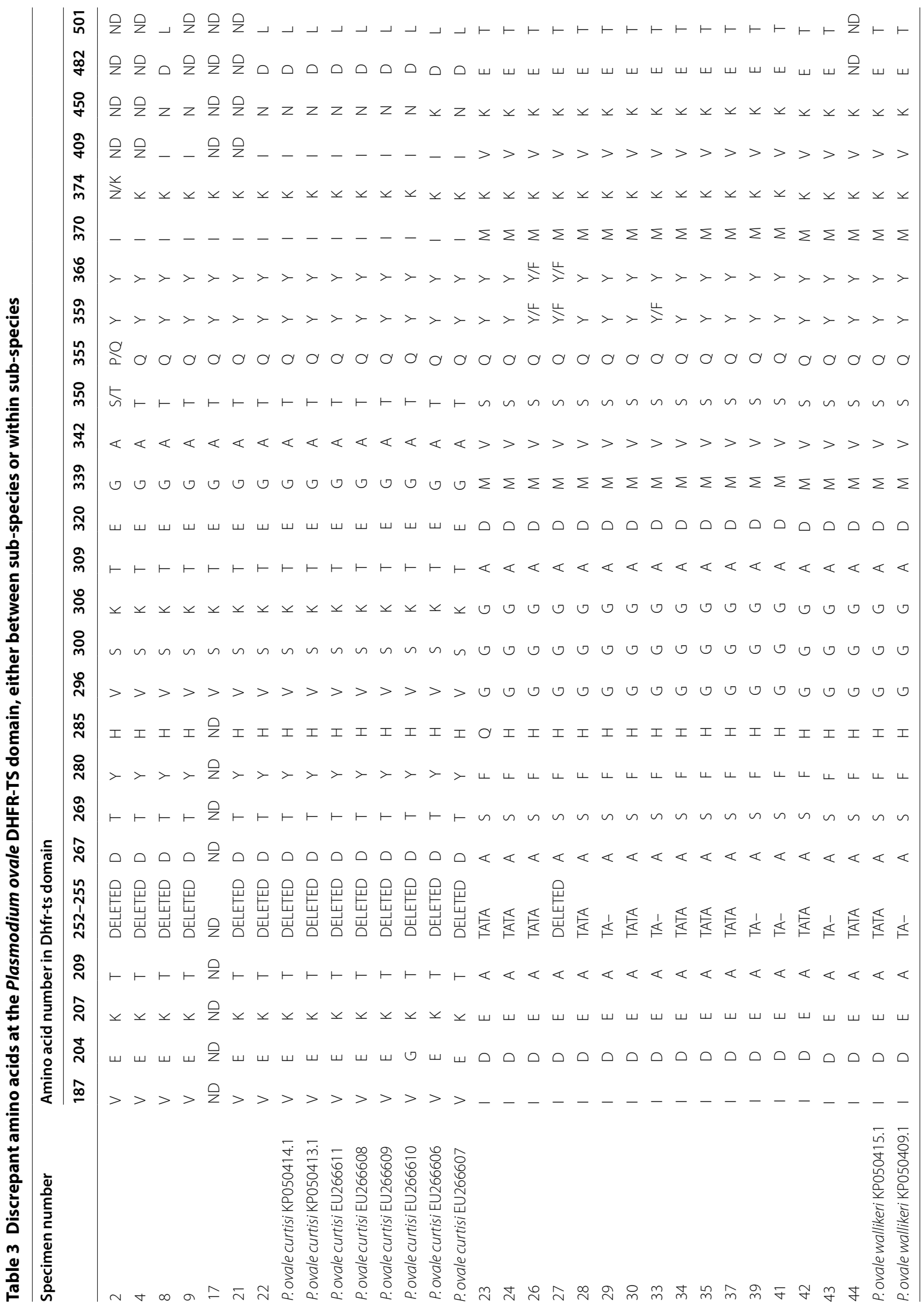




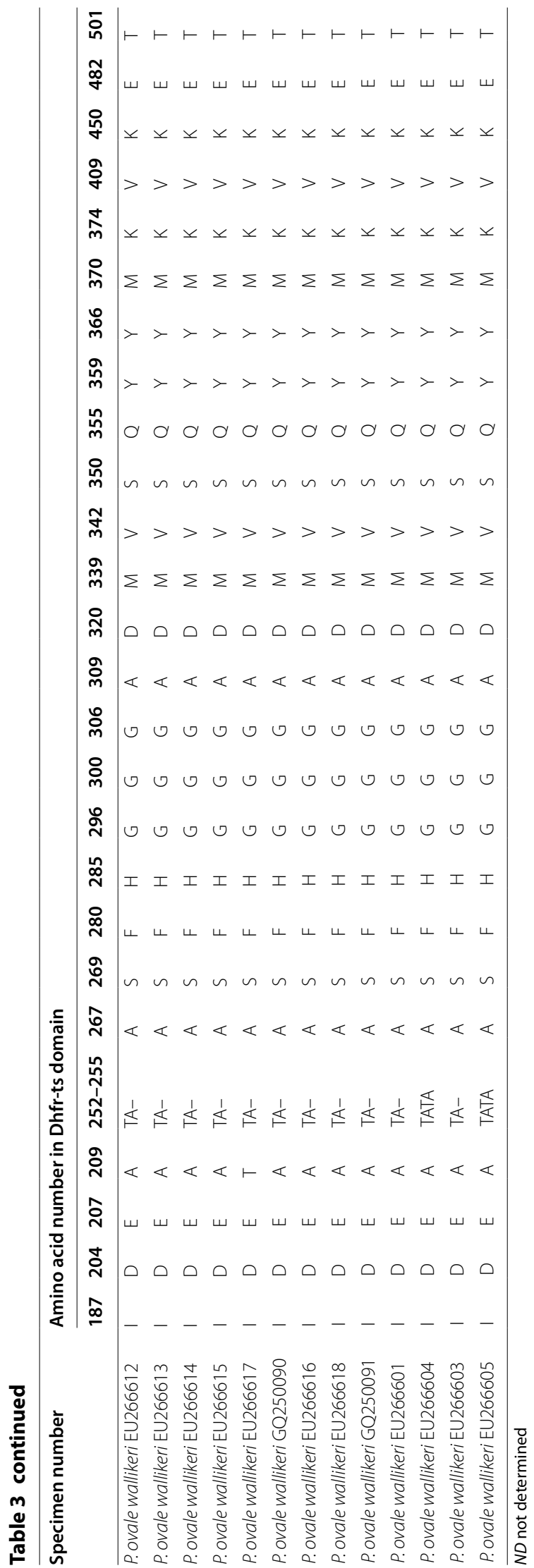


Table 4 Amino acids at the Dhfr-ts domain believed to affect antifolate binding

\begin{tabular}{|c|c|c|c|c|c|c|c|c|c|c|}
\hline \multirow[t]{2}{*}{ Plasmodium ovale isolate } & \multicolumn{10}{|c|}{ Amino acid number in Dhfr-ts domain relevant to antifolate binding } \\
\hline & 53 & 57 & 58 & 61 & 113 & 116 & 169 & 190 & 503 & 523 \\
\hline \multicolumn{11}{|l|}{ P. ovale curtisi KP050414.1 } \\
\hline 2 & ND & ND & ND & ND & ND & ND & I & $\mathrm{T}$ & ND & ND \\
\hline 4 & ND & $\mathrm{F}$ & $\mathrm{S}$ & $\mathrm{T}$ & S & $\mathrm{S}$ & । & $\mathrm{T}$ & $\mathrm{R}$ & C \\
\hline 8 & ND & $\mathrm{F}$ & $\mathrm{S}$ & $\mathrm{T}$ & $S$ & $S$ & । & $\mathrm{T}$ & $\mathrm{R}$ & C \\
\hline 9 & ND & $\mathrm{F}$ & $\mathrm{S}$ & T & $S$ & $S$ & I & $\mathrm{T}$ & $\mathrm{R}$ & C \\
\hline 17 & ND & ND & ND & ND & ND & ND & ND & ND & ND & ND \\
\hline 21 & ND & ND & ND & ND & ND & ND & । & $\mathrm{T}$ & ND & ND \\
\hline 22 & ND & $\mathrm{F}$ & S & T & $S$ & $S$ & I & $\mathrm{T}$ & $\mathrm{R}$ & C \\
\hline P. ovale curtisi EU266611 & $\mathrm{D}$ & $\mathrm{F}$ & $\mathrm{S}$ & T & $S$ & $S$ & I & $\mathrm{T}$ & $\mathrm{R}$ & C \\
\hline P. ovale curtisi EU266608 & $\mathrm{D}$ & $\mathrm{F}$ & $\mathrm{S}$ & $\mathrm{T}$ & $S$ & $S$ & । & $\mathrm{T}$ & $\mathrm{R}$ & C \\
\hline P. ovale curtisi EU266609 & $\mathrm{D}$ & $\mathrm{F}$ & $\mathrm{S}$ & $\mathrm{T}$ & $S$ & $S$ & । & $\mathrm{T}$ & $\mathrm{R}$ & C \\
\hline P. ovale curtisi EU266610 & $\mathrm{D}$ & $\mathrm{F}$ & $S$ & $\mathrm{~T}$ & $S$ & $S$ & । & $\mathrm{T}$ & $\mathrm{R}$ & C \\
\hline P. ovale curtisi EU266606 & $\mathrm{D}$ & $\mathrm{F}$ & $\mathrm{S}$ & $\mathrm{T}$ & S & $\mathrm{S}$ & । & $\mathrm{T}$ & $\mathrm{R}$ & C \\
\hline P. ovale curtisi EU266607 & $\mathrm{D}$ & $\mathrm{F}$ & $\mathrm{S}$ & $\mathrm{T}$ & S & $\mathrm{S}$ & । & $\mathrm{T}$ & $\mathrm{R}$ & C \\
\hline 23 & ND & ND & ND & ND & $S$ & S & । & $\mathrm{T}$ & $\mathrm{R}$ & C \\
\hline 24 & $\mathrm{D}$ & $\mathrm{F}$ & $S$ & $\mathrm{~T}$ & $S$ & $S$ & I & $\mathrm{T}$ & $\mathrm{R}$ & C \\
\hline 26 & ND & $\mathrm{F}$ & $S$ & $\mathrm{~T}$ & $S$ & $S$ & $\mathrm{~L}$ & $\mathrm{~T}$ & $\mathrm{R}$ & C \\
\hline 27 & ND & ND & ND & ND & $S$ & $S$ & I & $\mathrm{T}$ & $R$ & C \\
\hline 28 & ND & $\mathrm{F}$ & $S$ & $\mathrm{~T}$ & $S$ & $S$ & I & $\mathrm{T}$ & $R$ & C \\
\hline 29 & ND & $N D$ & ND & ND & $S$ & $S$ & I & $\mathrm{T}$ & $\mathrm{R}$ & C \\
\hline 30 & $D$ & $\mathrm{~F}$ & $S$ & $\mathrm{~T}$ & $S$ & $S$ & I & $\mathrm{T}$ & $R$ & C \\
\hline 33 & ND & $F$ & $S$ & $\mathrm{~T}$ & $S$ & $S$ & I & $\mathrm{T}$ & $\mathrm{R}$ & C \\
\hline 34 & ND & $F$ & $S$ & $\mathrm{~T}$ & $S$ & $S$ & I & $\mathrm{T}$ & $R$ & C \\
\hline 35 & $D$ & $F$ & $S$ & $\mathrm{~T}$ & $S$ & $S$ & I & $\mathrm{T}$ & $\mathrm{R}$ & C \\
\hline 37 & $D$ & $F$ & $S$ & $\mathrm{~T}$ & $S$ & $S$ & I & $\mathrm{T}$ & $R$ & C \\
\hline 39 & ND & $\mathrm{F}$ & $S$ & $\mathrm{~T}$ & $S$ & $S$ & I & $\mathrm{T}$ & $\mathrm{R}$ & C \\
\hline 41 & $D$ & $F$ & $S$ & $\mathrm{~T}$ & $S$ & $S$ & I & $\mathrm{T}$ & $R$ & C \\
\hline 42 & ND & $F$ & $S$ & $\mathrm{~T}$ & $S$ & $S$ & I & $\mathrm{T}$ & $R$ & C \\
\hline 43 & ND & $N D$ & ND & ND & $S$ & $S$ & I & $\mathrm{T}$ & $\mathrm{R}$ & C \\
\hline 44 & ND & $N D$ & ND & ND & $S$ & $S$ & I & $\mathrm{T}$ & $\mathrm{R}$ & C \\
\hline P. ovale wallikeri KP050415.1 & $\mathrm{D}$ & $\mathrm{F}$ & $S$ & $\mathrm{~T}$ & $S$ & $S$ & । & $\mathrm{T}$ & $\mathrm{R}$ & C \\
\hline P. ovale wallikeri KP050409.1 & $\mathrm{D}$ & $L$ & $\mathrm{R}$ & $\mathrm{T}$ & $S$ & $S$ & । & $\mathrm{T}$ & $\mathrm{R}$ & C \\
\hline P. ovale wallikeri EU266612 & $\mathrm{D}$ & $\mathrm{F}$ & $S$ & $\mathrm{~T}$ & $S$ & $S$ & । & $\mathrm{T}$ & $\mathrm{R}$ & C \\
\hline P. ovale wallikeri EU266613 & $\mathrm{D}$ & $\mathrm{F}$ & $S$ & $\mathrm{~T}$ & $S$ & $S$ & । & $\mathrm{T}$ & $\mathrm{R}$ & C \\
\hline P. ovale wallikeri EU266614 & $\mathrm{D}$ & $\mathrm{F}$ & $\mathrm{S}$ & $\mathrm{T}$ & S & $\mathrm{S}$ & । & $\mathrm{T}$ & $\mathrm{R}$ & C \\
\hline P. ovale wallikeri EU266615 & $\mathrm{D}$ & $\mathrm{F}$ & $S$ & $\mathrm{~T}$ & $S$ & $S$ & I & $\mathrm{T}$ & $\mathrm{R}$ & C \\
\hline P. ovale wallikeri EU266617 & $\mathrm{D}$ & $\mathrm{F}$ & $S$ & $\mathrm{~T}$ & $S$ & $S$ & I & $\mathrm{T}$ & $\mathrm{R}$ & C \\
\hline P. ovale wallikeri GQ250090 & $\mathrm{D}$ & $\mathrm{F}$ & $\mathrm{S}$ & $\mathrm{T}$ & $S$ & $S$ & । & $\mathrm{T}$ & $\mathrm{R}$ & C \\
\hline P. ovale wallikeri EU266616 & $\mathrm{D}$ & $\mathrm{F}$ & $\mathrm{S}$ & $\mathrm{T}$ & $S$ & $S$ & । & $\mathrm{T}$ & $\mathrm{R}$ & C \\
\hline P. ovale wallikeri EU266618 & $\mathrm{D}$ & $\mathrm{F}$ & $\mathrm{S}$ & $\mathrm{T}$ & S & $\mathrm{S}$ & I & $\mathrm{T}$ & $\mathrm{R}$ & C \\
\hline P. ovale wallikeri GQ250091 & $\mathrm{D}$ & $\mathrm{F}$ & $\mathrm{S}$ & $\mathrm{T}$ & $\mathrm{S}$ & $\mathrm{S}$ & I & $\mathrm{T}$ & $\mathrm{R}$ & C \\
\hline P. ovale wallikeri EU266601 & $\mathrm{D}$ & $\mathrm{F}$ & $S$ & $\mathrm{~T}$ & $S$ & $S$ & I & $\mathrm{T}$ & $\mathrm{R}$ & C \\
\hline P. ovale wallikeri EU266604 & $\mathrm{D}$ & $\mathrm{F}$ & $\mathrm{S}$ & $\mathrm{T}$ & $S$ & $S$ & I & $\mathrm{T}$ & $\mathrm{R}$ & C \\
\hline P. ovale wallikeri EU266603 & $\mathrm{D}$ & $\mathrm{F}$ & $\mathrm{S}$ & $\mathrm{T}$ & $S$ & $S$ & I & $\mathrm{T}$ & $\mathrm{R}$ & C \\
\hline P. ovale wallikeri EU266605 & $\mathrm{D}$ & $\mathrm{F}$ & $S$ & $\mathrm{~T}$ & $S$ & $S$ & । & $\mathrm{T}$ & $\mathrm{R}$ & C \\
\hline
\end{tabular}

ND not determined 
further challenge microscopists who rely on this as one of the features to distinguish $P$. ovale from the similarly low parasitaemic $P$. malariae, particularly when not all differentiating morphologies are present on the slide. As previously noted, $P$. ovale wallikeri cases appeared to increase more so than $P$. ovale curtisi in the past five years, and if this trend were to continue, the lack of Schüffner's stippling may further hinder interpretation of microscopy and RDT results. The lack of Schüffner's stippling among $P$. ovale wallikeri isolates joins other findings that the subspecies have distinguishing clinical characteristics, such as latency and degree of thrombocytopaenia, in addition to their genotype $[9,10]$. That said, molecular techniques are still the most accurate and specific method for determining sub-species of $P$. ovale.

Limitations of the study include a relatively small sample size which limited the ability to comment on the possible emergence of variant over classic $P$. ovale, an inability to investigate DHFR-TS enzyme activity, and possible variation in Schüffner's stippling visualization due to factors such as the age of the Giemsa stain or operator experience. As well, the attempt to account for time for specimen processing may be limited in terms of precision, as the exact time when blood was collected from patients was unavailable, meaning that this variable could only be analysed on the order of days rather than hours, the latter of which would have been ideal. Full clinical linkage of specimens was lacking and therefore data on latency of $P$. ovale infection or full travel details were unavailable. The limited availability of gene sequences in GenBank also restricted the ability to investigate the full $d h f r-t s$ region and other potential virulence factors that could theoretically differ between the sub-species.

Future studies, including whole genome sequencing of $P$. ovale, will facilitate identification of genes of other known Plasmodium virulence factors that have not been previously investigated in $P$. ovale. In particular, nucleotide and peptide heterogeneity between the two sub-species can be further explored across a larger sample size to extrapolate potential consequences in protein structure. Clinical outcomes can also be investigated prospectively to determine whether specific polymorphisms have any effect on delayed parasite clearance and treatment failure. Future prospective investigation of the Schüffner's stippling finding in $P$. ovale wallikeri versus $P$. ovale curtisi by diligent exclusion of competing factors, such as time to specimen processing, would further add to the literature around morphological identification, considering that microscopy remains the gold standard diagnostic test in malaria, and is often the only diagnostic test available in under-resourced settings.

\section{Conclusions}

This study demonstrates that the two $P$. ovale sub-species, $P$. ovale curtisi and $P$. ovale wallikeri, are increasing among travellers to West Africa, and do not differ significantly by parasitaemia, RDT positivity, or $18 \mathrm{~S}$ rRNA gene copy number, and may therefore be treated similarly from a clinical management perspective. A lack of discernible Schüffner's stippling on microscopic examination may be a feature specific to $P$. ovale wallikeri, and one which may significantly challenge the diagnosis of this typically low parasitaemic species, especially as loss of technical expertise in diagnostic laboratories continues. Although nucleotide polymorphisms in dhfr-ts were identified, it is unknown if they could lead to antifolate resistance, as they did not occur in regions known to confer antifolate resistance in other species such as P. falciparum. Further interrogation of the relevance of such genetic differences is warranted.

\section{Authors' contributions}

$\mathrm{RL}$ and MP contributed to data collection, analysis and interpretation, and to writing the manuscript. FR contributed to data collection and analysis, and to critical appraisal of the manuscript. AKB conceived the study, contributed to data analysis and interpretation, and to writing the manuscript. All authors critically reviewed the manuscript. All authors read and approved the final manuscript.

\section{Author details \\ ${ }^{1}$ McMaster University, Hamilton, Canada. ${ }^{2}$ Public Health Ontario Laborato- ries, Toronto, Canada. ${ }^{3}$ Tropical Disease Unit, Division of Infectious Diseases, Toronto General Hospital, University Health Network, 200 Elizabeth Street, 13EN-218, Toronto, ON M5G 2C4, Canada. ${ }^{4}$ University of Toronto, Toronto, Canada.}

\section{Acknowledgements}

We thank MR4 for providing us with Plasmodium small subunit ribosomal RNA clones contributed by Peter A Zimmerman. This work was funded by the Public Health Ontario Laboratories (PHOL) (AKB) and the Canadian Foundation for Infectious Diseases, 2015 CFID Summer Student Research Award (MP).

\section{Competing interests}

The authors declared that they have no competing interests.

Received: 20 June 2016 Accepted: 4 November 2016

Published online: 10 November 2016

\section{References}

1. Roucher C, Rogier C, Sokhna C, Tall A, Trape J-F. A 20-year longitudinal study of Plasmodium ovale and Plasmodium malariae prevalence and morbidity in a West African population. PLoS ONE. 2014;9:e87169.

2. Chavatte J-M, Tan SBH, Snounou G, Lin RTPV. Molecular characterization of misidentified Plasmodium ovale imported cases in Singapore. Malar J. 2015; 14:454.

3. Obare P, Ogutu B, Adams M, Odera JS, Lilley K, Dosoo D, et al. Misclassification of Plasmodium infections by conventional microscopy and the impact of remedial training on the proficiency of laboratory technicians in species identification. Malar J. 2013;12:113.

4. Bigaillon C, Fontan E, Cavallo J-D, Hernandez E, Spiegel A. Ineffectiveness of the Binax NOW malaria test for diagnosis of Plasmodium ovale malaria. J Clin Microbiol. 2005:43:1011. 
5. Talman AM, Duval L, Legrand E, Hubert V, Yen S, Bell D, et al. Evaluation of the intra- and inter-specific genetic variability of Plasmodium lactate dehydrogenase. Malar J. 2007;6:140

6. Khairnar K, Martin D, Lau R, Ralevski F, Pillai DR. Multiplex real-time quantitative PCR, microscopy and rapid diagnostic immuno-chromatographic tests for the detection of Plasmodium spp: performance, limit of detection analysis and quality assurance. Malar J. 2009;8:284.

7. Sutherland CJ, Tanomsing N, Nolder D, Oguike M, Jennison C, Pukrittayakamee $\mathrm{S}$, et al. Two nonrecombining sympatric forms of the human malaria parasite Plasmodium ovale occur globally. J Infect Dis. 2010:201:1544-50.

8. Tirakarn S, Riangrungroj P, Kongsaeree $P$, Imwong M, Yuthavong Y, Leartsakulpanich U. Cloning and heterologous expression of Plasmodium ovale dihydrofolate reductase-thymidylate synthase gene. Parasitol Int. 2012;61:324-32.

9. Nolder D, Oguike MC, Maxwell-Scott H, Niyazi HA, Smith V, Chiodini PL, et al. An observational study of malaria in British travellers: Plasmodium ovale wallikeri and Plasmodium ovale curtisi differ significantly in the duration of latency. BMJ Open. 2013;3:e002711.

10. Rojo-Marcos G, Rubio-Muñoz JM, Ramírez-Olivencia G, García-Bujalance S, Elcuaz-Romano R, Díaz-Menéndez M, et al. Comparison of imported Plasmodium ovale curtisi and P. ovale wallikeri infections among patients in Spain, 2005-2011. Emerg Infect Dis. 2014;20:409-16.

11. Choowongkomon K, Theppabutr S, Songtawee N, Day NP, White NJ, Woodrow CJ, et al. Computational analysis of binding between malarial dihydrofolate reductases and anti-folates. Malar J. 2010;9:65
12. Phuong M, Lau R, Ralevski F, Boggild AK. Sequence-based optimization of a quantitative real-time PCR assay for detection of Plasmodium ovale and Plasmodium malariae. J Clin Microbiol. 2014;52:1068-73.

13. Shokoples SE, Ndao M, Kowalewska-Grochowska K, Yanow SK. Multiplexed real-time PCR assay for discrimination of Plasmodium species with improved sensitivity for mixed infections. J Clin Microbiol. 2009;47:975-80.

14. Altschul SF, Gish W, Miller W, Myers EW, Lipman DJ. Basic local alignment search tool. J Mol Biol. 1990:215:403-10.

15. Untergasser A, Cutcutache I, Koressaar T, Ye J, Faircloth BC, Remm M, Rozen SG. Primer3-new capabilities and interfaces. Nucleic Acids Res. 2012;40:e115.

16. Koressaar T, Remm M. Enhancements and modifications of primer design program Primer3. Bioinformatics. 2007;23:1289-91.

17. Tamura K, Stecher G, Peterson D, Filipski A, Kumar S. MEGA6: molecular evolutionary genetics analysis version 6.0. Mol Biol Evol. 2013;30:2725-9.

18. Tanomsing N, Imwong M, Theppabutr S, Pukrittayakamee S, Day NPJ, White NJ, et al. Accurate and sensitive detection of Plasmodium species in humans by use of the dihydrofolate reductase-thymidylate synthase linker region. J Clin Microbiol. 2010;48:3735-7.

19. Maltha J, Gillet $P$, Jacobs J. Malaria rapid diagnostic tests in travel medicine. Clin Microbiol Infect. 2013;19:408-15.

20. Farcas GA, Zhong KJY, Lovegrove FE, Graham CM, Kain KC. Evaluation of the Binax Now ${ }^{\circledR}$ Ict test versus polymerase chain reaction and microscopy for the detection of malaria in returned travelers. Am J Trop Med Hyg. 2003;69:589-92.

\section{Submit your next manuscript to BioMed Central and we will help you at every step:}

- We accept pre-submission inquiries

- Our selector tool helps you to find the most relevant journal

- We provide round the clock customer support

- Convenient online submission

- Thorough peer review

- Inclusion in PubMed and all major indexing services

- Maximum visibility for your research

Submit your manuscript at www.biomedcentral.com/submit 